PRZEGLĄD NAUK HISTORYCZNYCH 2020, R. XIX, NR 1

http://dx.doi.org/10.18778/1644-857X.19.01.06

\title{
Przyjaźń polsko-węgierska według komunistów: polscy dyplomaci wobec Towarzystwa im. Adama Mickiewicza w Budapeszcie (1945-1948)
}

Streszczenie. W okresie międzywojennym w Budapeszcie zostało powołane do życia Towarzystwo im. Adama Mickiewicza. Jego głównym celem było rozwijanie kulturalnych relacji polsko-węgierskich oraz popularyzowanie wiedzy na temat polskiej literatury na Węgrzech. Kontynuowało działalność również podczas drugiej wojny światowej, chociaż Węgry były sojusznikami Niemiec. W okresie powojennym organizacja była negatywnie oceniana przez komunistycznych przedstawicieli dyplomatycznych Polski na Węgrzech. Doprowadzili do ograniczenia jej aktywności, w ostateczności natomiast do jej likwidacji w 1948 r.

Słowa kluczowe: Towarzystwo im. Adama Mickiewicza w Budapeszcie, polska placówka dyplomatyczna na Węgrzech, historia polskiej dyplomacji.

$\mathrm{P}$ odczas pobytu na emigracji Stanisław Gabriel Worcell, jeden z uczestników powstania listopadowego, miał okazję poznać wielu Węgrów, wśród nich Lajosa Kossutha. Kontakty te doprowadziły go do przekonania o silnych więzach łączących oba narody, co znalazło swój wyraz w słynnym stwierdzeniu: „Węgry a Polska, te dwa wiekuiste dęby, każdy $z$ nich wystrzelił pniem osobnym i odrębnym; ale ich korzenie szeroko rozłożone pod powierzchnią ziemi, plątały się i zrastały niewidomie. Stąd byt i czerstwość jednego, jest drugiemu warunkiem życia i zdrowia" ${ }^{1}$.

* Wydział Filozoficzno-Historyczny, Instytut Historii, Katedra Historii Powszechnej Najnowszej, e-mail: aleksandra.sylburska@uni.lodz.pl

1 S.G. W o r c e11, Stanisław Worcell o stosunkach polsko-węgierskich, Warszawa 1938 , s. 7. 
Fenomen ten jest powszechnie znany, historia dostarcza wielu przykładów polsko-węgierskiego braterstwa. Naturalna konsekwencją wzajemnej sympatii było powstawanie organizacji, które za cel stawiały sobie rozwijanie dobrych relacji między tymi krajami. Na Węgrzech największy rozkwit takich towarzystw nastapił w okresie międzywojennym. Pośród najważniejszych polonofilskich organizacji należałoby wymienić m.in. Związek Legionistów Polskich na Węgrzech, Węgiersko-Polskie Stowarzyszenie Studentów, Węgiersko-Polskie Koło Harcerzy. Większość z nich należała do Federacji Stowarzyszeń Węgiersko-Polskich, której celem była koordynacja działań na rzecz rozwoju relacji na linii BudapesztWarszawa ${ }^{2}$. Jednym $z$ najważniejszych członków Federacji był założony w 1912 r. Związek Węgiersko-Polski, który odegrał znacząca rolę w kreowaniu pozytywnego wizerunku Polski nad Dunajem jeszcze przed wybuchem pierwszej wojny światowej ${ }^{3}$. To w trakcie jednego $z$ jego spotkań zrodził się pomysł utworzenia nowej organizacji, której poświęcony jest ten artykuł.

Spotkanie odbyło się w 1927 r. Literat Béla Bevilaqua-Borsody wygłosił wykład poświęcony życiu intelektualnemu polskiej emigracji w Paryżu po powstaniu listopadowym. Postaciami centralnymi tego środowiska byli Adam Mickiewicz i Fryderyk Chopin. Pod wpływem tego wystapienia sekretarz Związku, przedsiębiorca i dziennikarz Leó Ferdinánd Miklósi zaproponował założenie stowarzyszenia literackiego imienia polskiego poety. Postulat spotkał się $z$ akceptacja, jednak prace nad powołaniem do życia nowej organizacji zajęły kolejne dwa lata. Pierwsze zebranie odbyło się 20 września 1929 r. w miejscu spotkań budapesztańskiej bohemy, czyli Klubie Fészek. Głównym celem nowego stowarzyszenia miało być podtrzymywanie i rozwijanie polsko-węgierskiej współpracy kulturalnej, głównym narzędziem - organizacja odczytów, uroczysto-

2 T. Gerencsér, A Magyar Mickiewicz Társaság első évtizede, „Acta Papensia” 2010, R. X, nr 3-4, s. 198. Do Federacji nie przystapili węgierscy legioniści. O stosunkach między kombatantami a innymi organizacjami polonofilskimi na Węgrzech por. E. Ko s s ew s ka, Zwiazek Legionistów Polskich wobec byłych legionistów na Wegrzech w latach 1938-1939, „Niepodległość i Pamięć” 2009, nr 31, s. 102-103.

3 Wspomnienie mjr. rez. Andrzeja Waisa byłego komendanta Placu Legionów Polskich w Budapeszcie pt. Formowanie Legionów Polskich na Wegrzech w r. 1914-1915, [w:] Źródła i dokumenty do dziejów legionistów węgierskich służących w Legionach Polskich w latach 1914-1918, red. E.L. Varga, T. Skoczek, Warszawa 2018, s. $114-116$. 
ści, przedstawień, a także troska o jej propagowanie w przestrzeni publicznej przez umieszczanie tablic pamiatkowych i pomników.

Pierwszym prezesem Towarzystwa im. Adama Mickiewicza został archeolog i literat baron Albert Nyáry (do 1933 r., kolejnymi byli Gyula Pekár i György Lukács). Prezesami honorowymi byli prymas Węgier Jusztinián Serédi oraz minister edukacji i religii Bálint Hóman. Oprócz przedstawicieli budapesztańskiej inteligencji i środowiska literackiego ważna rolę odgrywało honorowe uczestnictwo polityków, w tym marszałka parlamentu Gyuli Wlassicsa, a także ministra oświaty i wyznań religijnych hrabiego Kuno Klebelsberga. Duże zaangażowanie wykazywał również prezes Węgierskiej Akademii Nauk Albert Berzeviczy ${ }^{4}$. Podczas spotkania inauguracyjnego obecni byli polscy dyplomaci: sekretarz Georg Ciechanowski oraz konsul Aleksander Strakosz ${ }^{5}$.

Członkowie organizacji w dużej mierze przyczynili się do popularyzacji wiedzy o polskim wieszczu. János Sziklay dokonał przekładu Pana Tadeusza (jednak udało się opublikować tylko jego część); József Nagysólymosi oraz István Csapláros poświęcili mu wiele miejsca w swoich monumentalnych monografiach na temat polskiej literatury ${ }^{6}$. Oczywiście tematyka odczytów była dość różnorodna i nie koncentrowała się wyłącznie na postaci Adama Mickiewicza. Podobnie było w przypadku zawartości wydawnictwa „Biblioteka Węgiersko-Polska”, które ukazywało się pod egidą Towarzystwa ${ }^{7}$. Warto wspomnieć również o medalach, które orga-

${ }^{4}$ I. Csapláros, Zarys dziejów Węgierskiego Towarzystwa im. Adama Mickiewicza (przyczynki do wegierskiego polonofilstwa w XX wieku), „Rocznik Towarzystwa Literackiego imienia Adama Mickiewicza” 1969, nr 4, s. 63-64.

5 T. Gerencsér, op. cit., s. 190.

${ }^{6}$ Warto odnotować, że Adam Mickiewicz był znany węgierskim czytelnikom już w pierwszej połowie XIX w., przede wszystkim dzięki działalności Ferenca Toldy'ego oraz Gábora Kazincsy. Por. S. Kozocs a, Mickiewicz na Węgrzech, „Pamiętnik Literacki: Czasopismo Kwartalne Poświęcone Historii i Krytyce Literatury Polskiej" 1952, nr 40, s. 463-465. Na poczattku XX w. poezja Mickiewicza była tłumaczona przez m.in. Istvána Kertésza, Ernö Kovács-Karapa, Móra Petri, Gyulę Somogyváry, Istvána Szathmáry, Jánosa Sziklaya, Eszter Urbán oraz Bélę Vikár (T. Gerencsér, op. cit., s. 188).

7 Do 1938 r. pojawiło się siedem zeszytów „Biblioteki Węgiersko-Polskiej” (Książę Mieczysław Woroniecki-Korybut, Hungaria et Polonia. Bibliografia stosunków polsko-wegierskich, Królowie polscy na Węrzech, Polsko-węgierska umowa kulturalna i przyjaźń dwóch narodów, Polska i Andrássyowie, Regent Miklós Horthy na polskiej drodze, Polska i Andegawenowie). Wydano również inne prace, m.in. Báthory István Endre Veréssa, przekład wierszy Juliana Tuwima, Siódma jesień 
nizacja przyznawała co roku polskiemu i węgierskiemu literatowi albo naukowcowi za pracę dotyczaca polsko-węgierskich stosunków kulturalnych ${ }^{8}$.

Do połowy lat trzydziestych Towarzystwo im. Adama Mickiewicza funkcjonowało jako wydział literacki Stowarzyszenia Węgiersko-Polskiego. Obie instytucje łączyła postać Alberta Nyáry’ego, który był ich przewodniczącym. Zmiana nastapiła po jego śmierci w roku 1933, dopiero wówczas nowa organizacja wykazała się większą autonomią. Należy wspomnieć, że otrzymywała ona wsparcie finansowe zarówno od władzy węgierskiej, jak i poselstwa polskiego ${ }^{9}$.

Wybuch drugiej wojny światowej otworzył nowy rozdział w historii stosunków polsko-węgierskich. Premier Pál Teleki odmówił Niemcom, z którymi Węgry pozostawały w sojuszu, wykorzystania swojej kolei do przetransportowania niemieckiego wojska w celu ataku na Polskę. Dzięki uzyskanej w marcu 1939 r. wspólnej granicy (poprzez przejęcie przez Węgry Ukrainy Zakarpackiej) możliwa była ucieczka dziesiątków tysięcy polskich wojskowych i cywilnych z kraju okupowanego przez Niemcy i Zwiazek Radziecki. Towarzystwo im. Adama Mickiewicza musiało dostosować się do nowej i skomplikowanej pod względem politycznym sytuacji. Okazało się jednak, że po wybuchu wojny nie nastapiły żadne znaczące zmiany w jego działalności.

Członkowie Towarzystwa im. Adama Mickiewicza, po uzyskaniu zgody władz węgierskich, kontynuowali swoją pracę na rzecz popularyzacji polskiej literatury. Ponadto otoczyli opieka przedstawicieli kultury i nauki, którzy znaleźli się wśród polskich uchodźców. W dalszym ciagu organizowali odczyty i wykłady. W połowie 1941 i w 1942 r. nastapiło chwilowe zwolnienie tempa prac ze względu na przyłączenie się Węgier do działań wojennych po stronie Niemiec przeciwko Związkowi Radzieckiemu. Gdy w 1943 r. coraz bardziej prawdopodobne wydawało się, że w tym konflikcie sojusznik Budapesztu poniesie porażkę, działalność Towarzystwa się ożywiła ${ }^{10}$.

Arpáda Bardócza, Przyjaźń polsko-węgierska Alberta Nyáryego. Por. I. Cs a pláros, op. cit., s. 67-68.

8 Wśród nagrodzonych należy wymienić Polaków: Mariana Zdziechowskiego, Kazimierę Iłłakowiczównę i Jana Dąbrowskiego. Węgrzy, którzy otrzymali medal, to Adorján Vidéky, Endre Veréss, János Sziklay, Imre Lukinich (ibidem, s. 68-69).

9 T. Gerencsér, op. cit., s. 192, 195.

$10 \mathrm{~W}$ czasie drugiej wojny światowej Towarzystwo im. Adama Mickiewicza zorganizowało około 20 odczytów i wydarzeń artystycznych. Wśród występujących Polaków można wymienić późniejszego attaché prasowego polskiego poselstwa 
Co więcej, w spotkaniach organizacji aktywnie uczestniczyli polscy uchodźcy. Towarzystwo funkcjonowało do początków niemieckiej okupacji. Ze względu na swoja propolska postawę wielu jego członków musiało się ukrywać. Niektórzy $z$ nich byli represjonowani ${ }^{11}$. $Z$ powodu niemieckiej napaści niemożliwe było wydanie przygotowywanej przez Towarzystwo publikacji Polacy $i$ Wegrzy $w$ wieku XIX ${ }^{12}$.

Po zakończeniu wojny organizacja stanęła przed zadaniem wznowienia działalności $\mathrm{w}$ zmienionych warunkach geopolitycznych. Członkowie Towarzystwa im. Adama Mickiewicza przystapili do działania $z$ zapałem; wśród nich należałoby wymienić przewodniczącego Györgya Lukácsa ${ }^{13}$, Leó Ferdinánda Miklósiego, Bélę Bevilaqua-Borsody, dziennikarza Jenö Ungvári i historyka Lajosa Szimonidesza ${ }^{14}$. W 1945 r. zorganizowali dwie imprezy: 15 lipca $z$ okazji rocznicy bitwy pod Grunwaldem oraz 14 sierpnia w celu uhonorowania polskich uchodźców powracających do kraju. Pierwsze powojenne posiedzenie Towarzystwa im. Adama Mickiewicza odbyło się na początku 1946 r. z okazji 90 rocznicy śmierci polskiego wieszcza. Kolejne odczyty były organizowane co miesiąc, ewentualnie co dwa miesiace ${ }^{15}$. Warto dodać, że powstały nowe oddziały stowarzyszenia: Wydział Sportowy (Magyar Mickiewicz Társaság Sportügyi Osztálya) oraz Komitet Kobiet (Magyar

Tadeusza Fangrata, który prezentował swoje przekłady poezji Endre Adyego. Por. Raport prasowy za okres 15-30 listopada 1946 sporzadzony przez Tadeusza Fangrata, 4 XII 1946, Archiwum Ministerstwa Spraw Zagranicznych w Warszawie [dalej: AMSZ], Departament Prasy i Informacji [dalej: DPI], 21/93/1267, k. 98.

${ }^{11}$ Sekretarz János Kertész został zastrzelony podczas próby ucieczki po wcieleniu go do wojskowej brygady robotniczej. Leó Ferdinánd Miklósi był torturowany przez Gestapo. Członek zarządu Jenő Mohácsi został aresztowany przez Gestapo i zamordowany w pociagu w drodze do Auschwitz. W tym obozie zmarł Kornél Tábori. Sekretarz Edgár Palóczi został zastrzelony w 1944 r. Por. I. Cs a pláros, op. cit., s. 69-72.

${ }^{12}$ Fragmenty rękopisu zostały wydane w 2018 r. Magyarok és lengyelek a 19. században. Egy 1944-ben betiltott könyv, ed. M. Mitrovits, Budapest 2018.

${ }^{13}$ Nie należy mylić go ze znanym filozofem o tym samym imieniu i nazwisku. György Lukács (1865-1950) był z wykształcenia prawnikiem i politykiem, zajmował stanowisko m.in. ministra wyznań i oświaty (1905-1906), zasiadał również w parlamencie jako poseł (1910-1931). Por. Lukács György, [w:] Magyar életrajzi lexikon, t. I, red. Á. Kenyeres, Budapest 1967. Leksykon jest dostępny na stronie internetowej Országos Széchényi Könyvtár, http://mek.oszk.hu/00300/00355/ html/ABC09006/09681.htm (dostęp: 16 IV 2019).

${ }^{14}$ I. Cs a pláros, op. cit., s. 73.

15 T. Gerencsér, A Magyar Mickiewicz Társaság második évtizede, „Acta Papensia" 2011, R. XI, nr 3-4, s. 172-173. 
Mickiewicz Társaság Hölgybizottsága). Do drugiego należała m.in. żona Árpáda Szakasitsa ${ }^{16}$.

Zaangażowanie i zapał członków organizacji zostały dostrzeżone przez pierwszego powojennego polskiego chargé d'affaires na Węgrzech Piotra Szymańskiego ${ }^{17}$. Porównał je $z$ innymi stowarzyszeniami polonijnymi, które nie podejmowały konkretnej działalności, oczekujac (w jego przekonaniu) rezultatu przemian politycznych w państwie. Wynikało to $z$ tego, że członkowie tych instytucji rekrutowali się w większości ze sfer arystokratycznych, zatem w dużej mierze byli niechętni komunistom i sami byli przez nich negatywnie postrzegani ${ }^{18}$. Wśród członków przeważała sympatia dla Polski przedwojennej. Dodatkowym problemem była hermetyczność tej organizacji. Nowe osoby miały utrudniony do niej dostęp, ale pod koniec 1946 r., dzięki prywatnym kontaktom polskiego attaché prasowego Tadeusza Fangrata, udało się wprowadzić do stowarzyszenia kilka młodszych osób o poglądach „bardziej postępowych”19. Obawy o zbyt konserwatywny charakter stowarzyszenia podzielało również polskie Ministerstwo Spraw Zagranicznych (dalej: MSZ) ${ }^{20}$. Mimo to pracownicy polskiego poselstwa uczestniczyli w posiedzeniach towarzystwa, m.in. 15 listopada 1946 r. z okazji 100 rocznicy narodzin Henryka Sienkiewicza ${ }^{21}$.

\footnotetext{
${ }^{16}$ Id e m, A Magyar Mickiewicz Társaság első..., s. 197.

17 Piotr Szymański był chargé d'affaires w Budapeszcie od lipca 1946 do lipca $1947 \mathrm{r}$.

${ }^{18}$ Warto dodać, że komunistom zależało przede wszystkim na nawiazaniu oficjalnej współpracy polsko-węgierskiej. Działalność tego typu organizacji, których członkowie wywodzili się $z$ okresu międzywojennego, była niemile widziana. Jednak należy zaznaczyć, że to oni jako pierwsi po zakończeniu wojny zaczęli troszczyć się o kulturalne kontakty między krajami. Aktywność państwowa rozpoczęła się później. Por. T. G ere n csér, M. Grad, M. Mitrovits, Magyar zászló a Visztula felett. Magyar-legyel kapcsolatok a magyar diplomácia szemével, Budapest 2019, s. 97 i n.

19 Piotr Szymański do Józefa Olszewskiego, 10 I 1947, AMSZ, Departament Polityczny [dalej: DP], 6/26/394, k. 129-130; Sprawozdanie prasowe za okres 1-15 grudnia 1946, ibidem, 6/26/400, k. 189. Status organizacji przewiduje liczbę członków - 60 osób. Por. Raport prasowy za okres 15-30 listopada 1946 sporzadzony przez Tadeusza Fangrata, 4 XII 1946, ibidem, 21/93/1267, k. 98; Raport prasowy za okres 1-15 listopada 1946 sporzadzony przez Tadeusza Fangrata, 20 XI 1946, ibidem, DPI, 21/93/1267, k. 76.

${ }^{20}$ Aleksander Jackowski do Tadeusza Fangrata, 13 XII 1946, ibidem, 21/98/ 1309, karty bez paginacji.

${ }^{21}$ I. Cs a plá ro s, op. cit., s. 74; T. Gere n c sér, A Magyar Mickiewicz Társaság második..., s. 173 i n.
} 
Pewnym sukcesem było uzyskanie przez poselstwo wpływu na treść artykułów zawartych w wydawanym przez Towarzystwo im. Adama Mickiewicza „Magyar-Lengyel Kurír”22. W raporcie dyplomatycznym przesłanym do MSZ w Warszawie została zawarta krytyka pierwszego numeru pisma wydanego w październiku $1946 \mathrm{r}$. Według autora raportu (najprawdopodobniej kierownika Attachatu Prasowego Tadeusza Fangrata): „wydany starannie, zredagowany umiejętnie zatraca się w reminiscencjach historycznych, a o nowej Polsce, o jej wielkich osiągnięciach i walkach zachowuje milczenie"23. Redaktorem pisma był Jenö Ungvári, który został pouczony, że czasopismo w tej postaci nie przysłuży się tworzeniu dobrych relacji polsko-węgierskich, ponieważ nie poświęca wystarczającej uwagi obecnej sytuacji. W listopadzie można już było dostrzec efekty krytyki, gdyż redaktor w artykule wstępnym nawoływał do kształtowania relacji „w duchu postępu i demokracji”24. Mimo to węgierskie MSZ zdecydowało się na cofnięcie swojego dofinansowania dla periodyku ze względu na „nieprzyjemne tendencje, jakie ujawnia ideologia pisma" 25 . Tadeusz Fangrat musiał w tej sprawie interweniować na początku 1947 r. i udało mu się przekonać Węgrów do zmiany decyzji ${ }^{26}$.

Pomysł utworzenia nowego towarzystwa przyjaźni polsko-węgierskiej, które byłoby zbudowane na bazie członków wywodzacych się $z$ niższych grup społecznych oraz sprzyjające komunistom, pojawił się już na początku funkcjonowania polskiego poselstwa. Idea ta była podyktowana życzeniem polskiego MSZ, aby wszystkie organizacje polsko-węgierskie zostały rozwiązane i by w ich miejsce powołać zupełnie nowe stowarzyszenie ${ }^{27}$. W przekonaniu Piotra Szymańskiego brakowało jednak osób, które byłyby gotowe zaangażować się w jego budowę i działalność ${ }^{28}$.

${ }^{22}$ Piotr Szymański do Józefa Olszewskiego, 10 I 1947, AMSZ, DP, 6/26/394, k. 129-130. W Országos Széchényi Könyvtár w Budapeszcie znajduje się tylko kilka egzemplarzy pisma z okresu między 30 IX 1946 a 15 X 1947 r.

${ }^{23}$ Sprawozdanie prasowe za okres 1-15 grudnia 1946, AMSZ, DP, 6/26/400, k. 190 .

24 Ibidem.

${ }^{25}$ Notatka $z$ rozmowy Tadeusza Fangrata z Jenö Heltaiem, 21 I 1947, AMSZ, DP, 6/26/404, k. 3.

26 Ibidem.

27 Sprawozdanie z kontaktów sporządzone przez Piotra Szymańskiego, 3 X 1946, ibidem, 6/26/401, k. 1-6; Maria Wierna do Piotra Szymańskiego, 26 XI 1946, ibidem, 6/26/401, k. 7.

${ }^{28}$ Piotr Szymański do Józefa Olszewskiego, 10 I 1947, AMSZ, DP, 6/26/394, k. 130. 
Węgierscy politycy mieli dokładnie takie same plany w stosunku do istniejacych organizacji. W styczniu 1947 r. Dyrektor Departamentu Politycznego MSZ Jenö Heltai w rozmowie $z$ Tadeuszem Fangratem przyznał, że komuniści chcieli utworzyć nowe Towarzystwo Polsko-Węgierskie, którego członkami byliby przedstawiciele wszystkich partii, w tym József Antall ${ }^{29}$. Dopiero jednak poszukiwali osoby „odpowiedniej” do pełnienia funkcji sekretarza tej insty-

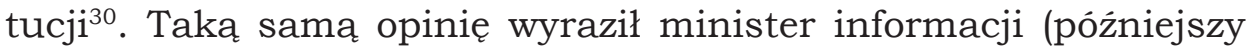
minister spraw zagranicznych) Ernő Mihályfi w rozmowie $z$ Piotrem Szymańskim ${ }^{31}$. Węgierscy komuniści zezwolili na działalność Towarzystwa im. Adama Mickiewicza do czasu powołania nowej organizacji, ale miało ono zostać poddane obserwacji ${ }^{32}$.

Informacja o planach utworzenia nowego stowarzyszenia dotarła do członków Towarzystwa im. Adama Mickiewicza. W maju 1947 r. doszło do rozmowy między jego prezesem Györgyem Lukácsem a Piotrem Szymańskim, podczas której Węgier zapewniał, że członkowie jego organizacji byliby w stanie realizować cele wyznaczone nowemu Towarzystwu Węgiersko-Polskiemu. Rozmowa była trudna, ponieważ Lukács chciał wymusić na Szymańskim informacje, jakie byłyby oczekiwania polskiego poselstwa wobec Towarzystwa im. Adama Mickiewicza. Polski dyplomata nie chciał podejmować dyskusji na ten temat, sugerując, że organizacja nie była i nie będzie w stanie pełnić funkcji Towarzystwa Węgiersko-Polskiego. Twierdził, że działalność Towarzystwa im. Adama Mickiewicza miała wyłącznie charakter literacki, ponadto brakowało mu doświadczenia w organizowaniu imprez masowych (czemu Lukács zaprzeczył). Gdy okazało się, że Węgier nie zrezygnuje, dopóki nie otrzyma konkretnej odpowiedzi, Szymański wyjaśnił, że towarzystwo przyjaźni musi promować wiedzę o „nowej” Polsce oraz zachodzacych w niej

${ }^{29}$ József Antall senior był odpowiedzialny za opiekę nad polskimi uchodźcami w czasie drugiej wojny światowej jako kierownik Biura do Spraw Uchodźców IX Departamentu Ministerstwa Spraw Wewnętrznych. Wspomnienia dotyczace tego ważnego epizodu w relacjach węgiersko-polskich zawarł w: J. Anta11, Schronienie uchodźców, Warszawa 2009.

${ }^{30}$ Notatka $z$ rozmowy Tadeusza Fangrata $z$ Jenö Heltaiem, 21 I 1947, AMSZ, DP, 6/26/404, k. 3; Notatka Tadeusza Fangrata, 21 I 1947, Instytut Pamięci Narodowej Biuro Udostępniania, Zarząd II Wydziału Sztabu Generalnego Wojska Polskiego, 2602/2584, k. 87.

${ }^{31}$ Notatka z rozmowy Piotra Szymańskiego z Ernő Mihályfim, 25 IV 1947, AMSZ, DP, 6/27/407, k. 193.

32 Notatka $z$ rozmowy Tadeusza Fangrata $z$ Antalowa i Imre Trencsenyi-Waldapfelem, 24 I 1947, ibidem, 6/26/404, k. 4-5. 
przemianach. Lukács stwierdził, że Towarzystwo im. Adama Mickiewicza może taką działalność prowadzić33.

Kilkanaście dni później odbyło się w poselstwie kolejne spotkanie $z$ przedstawicielami organizacji. Lajos Szimonidesz chciał przekonać Piotra Szymańskiego, aby poparł starania Towarzystwa im. Adama Mickiewicza w związku z przygotowaniami do obchodów 100 rocznicy wybuchu Wiosny Ludów. Stowarzyszenie chciało zająć się organizacją imprezy, jednak nie spotkało się to $z$ akceptacja polskich dyplomatów. Szymański stwierdził, że za przygotowania odpowiedzialne są rządy węgierski oraz polski, które będą bezpośrednio kontaktowały się $z$ instytucjami kulturalnymi oraz naukowcami w celu uzyskania pomocy. Oznaczało to odrzucenie propozycji Węgrów. Jenö Ungvári zwrócił się z prośbą o wsparcie finansowe dla „Magyar-Lengyel Kurír”, ale nie uzyskał od polskiego chargé d'affaires obietnicy jej spełnienia ${ }^{34}$.

Miesiąc później na temat działalności organizacji rozmawiali Leó Ferdinánd Miklósi i Tadeusz Fangrat. Ponieważ zbliżały się wybory zarządu, Węgier postanowił „poradzić się”, jakiego wyboru oczekiwałoby poselstwo. Fangrat zaproponował osoby o lewicowych poglądach: ówczesnego ministra religii i oświaty Gyulę Ortutaya (Partia Drobnych Posiadaczy) albo Árpáda Szakasitsa. Miklósi, nie będąc przekonanym, czy w danym momencie umiałby przeforsować takie rozwiązanie, postanowił odłożyć wybory w czasie ${ }^{35}$. Rozmowa ta świadczyła jednak o determinacji członków organizacji, którym zależało na utrzymaniu dobrych relacji z polskim poselstwem.

Rozpoczęły się przygotowania, których celem było utworzenie Towarzystwa Węgiersko-Polskiego. Jednocześnie nie rezygnowano z działalności Towarzystwa im. Adama Mickiewicza. Jego członkowie wzięli nawet udział w spotkaniu organizacyjnym nowego stowarzyszenia. Wygłosili przemówienie, w którym serdecznie witali założycieli nowej organizacji i wyrażali zadowolenia $z$ jej powstania $^{36}$. W trakcie spotkania wybrano prezesa, którym został Ernő Mihályfi. Podczas przemówienia podkreślił on, jaki charakter miała mieć nowo powstałe stowarzyszenie i jaki jest jego główny cel:

${ }^{33}$ Notatka $z$ rozmowy Piotra Szymańskiego z Györgyem Lukácsem, 8 V 1947, ibidem, 6/27/407, k. 195-196.

${ }^{34}$ Notatka $z$ rozmowy Piotra Szymańskiego $z$ delegatami Towarzystwa im. Mickiewicza, 23 V 1947, ibidem, 21/93/1268, k. 174.

${ }_{35}$ Notatka $z$ rozmowy Tadeusz Fangrata $z$ Leó Ferdinándem Miklósim, 8 VI 1947, ibidem, 6/27/407, k. 197-198.

${ }^{36}$ T. Geren csér, A Magyar Mickiewicz Társaság második..., s. 179. 
budowa przyjaźni polsko-węgierskiej na „postępowych” zasadach. Zaznaczył, że organizacja nie będzie miała charakteru elitarnego, jak to było dotychczas, lecz powinna obejmować swoim działaniem „szerokie masy pracujace". W zarządzie nowego stowarzyszenia zasiadli głównie politycy: minister przemysłu z Partii Socjaldemokratycznej Antal Bán, minister komunikacji z Węgierskiej Partii Komunistycznej Ernő Gerö oraz Ferenc Erdei z Narodowej Partii Chłopskiej. Wśród członków kierownictwa znaleźli się także chemik Albert Szent-Györgyi, polscy dyplomaci Tadeusz Fangrat oraz Zbigniew Udziela, a także pracujący w Instytucie Polskim slawista István Kniezsa oraz Dénes Szabó, który został sekretarzem organizacji. Jego zastępcą wybrano pisarza Lajosa Mesterháziego. Ostatnim punktem zebrania była redakcja telegramu do Bolesława Bieruta $z$ informacja o powstaniu nowego stowarzyszenia oraz wyrazami uznania dla narodu polskiego ${ }^{37}$.

Wiele wskazywało na to, że nowa organizacja będzie miała zupełnie inny charakter niż Towarzystwo im. Adama Mickiewicza. Najważniejsze zasady zostały przedstawione przez Mihályfiego $\mathrm{w}$ przemówieniu inauguracyjnym. Znamienne były słowa prezesa, że oba narody połączyło wyzwolenie spod okupacji niemieckiej przez Związek Radziecki, który był jednocześnie gwarantem rozwoju demokracji w tych państwach ${ }^{38}$. O zmianie świadczył także skład zarządu, którego większość stanowili politycy i dyplomaci. Wybrani przedstawiciele nauki i kultury natomiast nie byli przypadkowi - w jednej $z$ notatek przesłanych do MSZ Tadeusz Fangrat przyznawał, że Szabó oraz Mesterházi cieszyli się zaufaniem pracowników polskiego poselstwa ${ }^{39}$. Również plan wyposażenia siedziby nowego towarzystwa świadczył o jego odmiennym charakterze: oprócz polskiej flagi oraz obrazów $z$ wizerunkami Józefa Bema, Fryderyka Chopina i Adama Mickiewicza miały pojawić się również

37 Notatka $z$ zebrania organizacyjnego Towarzystwa Polsko-Węgierskiego sporządzona przez Zbigniewa Udzielę, AMSZ, DP, 6/28/419, k. 25; Sprawozdanie prasowe za okres 1-30 czerwca 1947 sporządzone przez Zbigniewa Udzielę, 10 VII 1947, AMSZ, DPI, 21/93/1268, k. 179-180; Megalakult Magyar-Lengyel Társaság [Powstało Towarzystwo Węgiersko-Polskie], „Magyar-Lengyel Kurír”, 31 VII 1947, s. 5.

38 Artykuł pt. Prasa wegierska o powstaniu Towarzystwa Polsko-Wegierskiego w „Kis Újság”, 15 VI 1947, AMSZ, DP, 6/28/419, k. 28.

${ }^{39}$ Notatka Tadeusza Fangrata, 5 VII 1947, AMSZ, DPI, 21/98/1309, karty bez paginacji. 
portrety Árpáda Szakasitsa, Mátyása Rákosiego i Bolesława Bieruta $^{40}$. Wszystkie te decyzje świadczyły o tym, że nowo powstałe towarzystwo przyjaźni polsko-węgierskiej nie będzie koncentrowało się tylko na kulturze, ale w tej samej mierze, jeśli nie w większej, na bieżącej polityce. Ponadto zostało poddane komunistycznej kontroli. Odpowiadali za nia nie tylko węgierscy politycy znajdujący się w zarzązie, lecz także polscy dyplomaci, których zadaniem była troska o „odpowiedni” charakter organizacji.

Kolejne miesiące mogłyby świadczyć o tym, że współistnienie dwóch organizacji przyjaźni polsko-węgierskiej było możliwe. Towarzystwo im. Adama Mickiewicza kontynuowało swoja działalność i organizowało liczne wydarzenia. W dniu 22 lipca 1947 r., w rocznicę ogłoszenia Manifestu Lipcowego, zorganizowało posiedzenie, na którym był obecny pracownik poselstwa Stanisław Findor ${ }^{41}$. Dnia 29 września 1947 r. odbyła się akademia z okazji 150 rocznicy powstania polskiego hymnu. Podczas spotkania przemówienia wygłosili polski poseł Alfred Fiderkiewicz ${ }^{42}$ oraz referent prasowy Janusz Moszczeński ${ }^{43}$. W dniu 20 października 1947 r., w związku $z$ wizyta polskiej delegacji handlowej w Budapeszcie, Towarzystwo zorganizowało wieczór artystyczny ${ }^{44}$. Polscy dyplomaci byli również obecni na zebraniu 17 listopada 1947 r., podczas którego wygłoszono odczyty na temat udziału Polaków w węgierskiej Wiośnie Ludów w ramach przygotowań do obchodów 100 rocznicy tego wydarzenia ${ }^{45}$.

Dnia 19 listopada 1947 r. odbyło się zebranie przedstawicieli Towarzystwa im. Adama Mickiewicza oraz Towarzystwa Polsko-Węgierskiego, którego celem było omówienie zasad wspólnej redakcji „Magyar-Lengyel Kurír”. Polskiemu poselstwu zależało na

40 A Magyar-Lengyel Társaság berendezési leltára, 28 VI 1949, Magyar Országos Levéltár, Népművelési Minisztérium 1949-1957. Ellenőrzési Osztály 19461956 XIX-I-3-r, 2. d., 38. t., 1000.38-9, karty bez paginacji.

${ }^{41}$ T. Gerencsér, A Magyar Mickiewicz Társaság második..., s. 180.

${ }^{42}$ Alfred Fiderkiewicz był posłem w Budapeszcie od lipca 1947 do czerwca 1949 r.

${ }^{43}$ Sprawozdanie $z$ akademii urządzonej przez Towarzystwo im. Adama Mickiewicza $z$ okazji 100-lecia hymnu polskiego sporządzone przez Zbigniewa Udzielę, 6 X 1947, AMSZ, DPI, 21/93/1268, k. 229.

${ }^{44}$ Raport prasowy za miesiąc październik 1947 sporządzony przez Zbigniewa Udzielę, 3 XI 1947, ibidem, 21/93/1268, k. 240.

45 Sprawozdanie $z$ zebrania Towarzystwa im. Mickiewicza sporzadzone przez Janusza Moszczeńskiego, 17 XI 1947, AMSZ, DP, 6/28/419, k. 16. 
tym, aby pismo nabrało bardziej „postępowego” charakteru. W trakcie spotkania okazało się jednak, że nie było możliwości podjęcia współpracy z uwagi na opór Lajosa Szimonidesza oraz Leona Ferdinánda Miklósiego. Wobec tego redakcja otrzymała zakaz wydawania pisma od dnia 30 listopada ${ }^{46}$.

Zgoda na funkcjonowanie Towarzystwa im. Adama Mickiewicza nie wynikała $z$ aprobaty dla jego działalności ${ }^{47}$. Najprawdopodobniej była efektem braku przejawów aktywności Towarzystwa Węgiersko-Polskiego. Dnia 17 listopada 1947 r. polski attaché prasowy Zbigniew Udziela odbył rozmowę $z$ Ernő Mihályfim na temat organizacji Tygodnia Polskiego w Budapeszcie. Był on planowany na połowę stycznia 1948 r. i miał być połączony z podpisaniem polsko-węgierskiej umowy kulturalnej. Mihályfi narzekał jednak na to, że nowo powstałe Towarzystwo Węgiersko-Polskie od zebrania inauguracyjnego nie przejawiało żadnej inicjatywy. W przekonaniu prezesa była to wina członków, w tym przede wszystkim sekretarza Dénesa Szabó ${ }^{48}$. W rzeczywistości organizacją wydarzenia zajmował się wyłącznie szef towarzystwa. Stanowiło to problem $z$ punktu widzenia węgierskich komunistów, którym zależało na profesjonalnym i uroczystym przebiegu Tygodnia Polskiego ${ }^{49}$.

${ }^{46}$ Raport prasowy za miesiac listopad 1947 sporzadzony przez Zbigniewa Udzielę, 2 XII 1947, AMSZ, DPI, 21/93/1268, k. 262-263; Sprawozdanie prasowe za okres 1-31 stycznia 1948 sporzadzone przez Zbigniewa Udzielę, 4 II 1948, ibidem, 21/94/1272, karty bez paginacji. Ostatni numer pisma pojawił się $15 \mathrm{X}$ 1947 r. Por. T. Ge re n cs ér, A Magyar Mickiewicz Társaság második..., s. 192.

47 Jeszcze przed utworzeniem Towarzystwa Polsko-Węgierskiego Piotr Szymański krytycznie odnosił się do wszystkich organizacji, które nawiązywały do tradycyjnej polsko-węgierskiej przyjaźni. W jednym $z$ raportów informował o taktyce stosowanej przez poselstwo, która nie pozwalała na „zwekslowanie stosunków polsko-węgierskich na tory omijania nowej rzeczywistości polskiej” przez te organizacje. Gdyby natomiast chciały kontynuować tę działalność, doprowadziłoby to do ich „samolikwidacji” bądź całkowitego podporządkowania. Por. Piotr Szymański do Józefa Olszewskiego, 19 V 1947, AMSZ, DP, 6/27/407, k. 160.

48 Notatka $z$ rozmowy Zbigniewa Udzieli z Ernő Mihályfim, 17 XI 1947, ibidem, $6 / 28 / 419, k$. 33. Już wcześniej sugerował w rozmowie $z$ Lajosem Mesterházim, że na jego miejsce powinna być zatrudniona inna osoba, która za swoją działalność pobierałaby wynagrodzenie. Węgrzy uważali również, że polskie poselstwo nie wspiera w odpowiedni sposób działalności organizacji. Por. Mesterházi jelentése Farkasnak a Magyar-Lengyel Társaság mükődésévől, 21 X 1947, Politikatörténeti és Szakszervezeti Levéltár, Magyar Kommunista Párt, 274. f., 10. cs., 84. ő. e., k. 1.

49 Raport polityczny za okres 12 grudnia 1947 - 15 stycznia 1948 sporządzony przez Alfreda Fiderkiewicza, 14 I 1948, AMSZ, DP, 6/28/427, k. 2. 
Polscy dyplomaci mieli własną opinię na temat przyczyn zachowania członków nowego stowarzyszenia. W przekonaniu Tadeusza Fangrata tradycyjna przyjaźń polsko-węgierska straciła na znaczeniu. Członkowie zostali wybrani ze względu na swoje poglądy polityczne, a nie zainteresowania, i po prostu nie mieli wiedzy oraz zapału do pracy $^{50}$.

Sytuacja zmieniła się na początku 1948 r., gdy w opinii Zbigniewa Udzieli Towarzystwo Węgiersko-Polskie zintensyfikowało swoją działalność, głównie wobec wymagań związanych $z$ organizacją Tygodnia Polskiego. Przewidywał, że zaangażowanie w prace zwiększą się jeszcze bardziej, gdy już niedługo organizacja otrzyma siedzibę ${ }^{51}$. W kolejnych miesiącach Towarzystwo Węgiersko-Polskie uzyskało większe środki finansowe, co wpłynęło na jego aktywność ${ }^{52}$. Pod koniec 1948 r. oraz na początku kolejnego roku w opinii węgierskiej władzy oraz polskiego poselstwa Towarzystwo Polsko-Węgierskie w Budapeszcie rozwijało się w pożądanym kierunku i działało coraz prężniej. Podczas dwóch miesięcy: od 14 września do 14 listopada 1948 r. zorganizowało osiem spotkań. Tematyka i miejsce przeprowadzenia niektórych $z$ nich świadczyły o zmianie, jaka nastapiła w działalności nowej organizacji w porównaniu $z$ Towarzystwem im. Adama Mickiewicza. W tym zakresie można wymienić odczyt poświęcony rozwojowi współczesnej literatury polskiej, współczesnej Polsce, a także wieczór artystyczno-muzyczny zorganizowany dla Związku Zawodowego Tramwajarzy Węgierskich oraz węgierskiej Polonii (w większości przedstawiciele robotniczej kolonii polskiej $z$ okolicy kopalni kamienia w dzielnicy Budapesztu Köbánya) ${ }^{53}$.

Alfred Fiderkiewicz $z$ dużym uznaniem wypowiadał się na temat wydarzeń z początku 1949 r., które w jego przekonaniu świadczyły o dużej aktywności Towarzystwa Polsko-Węgierskiego. Zorganizowało ono dwa wieczory kulturalno-oświatowe w fabryce MÁVÁG

50 Raport polityczny za okres 6 kwietnia - 3 maja 1948 sporządzony przez Tadeusza Fangrata, 3 V 1948, ibidem, k. 78.

${ }^{51}$ Sprawozdanie prasowe za miesiąc styczeń 1948 sporządzone przez Zbigniewa Udzielę, 4 II 1948, AMSZ, DPI, 21/94/1272, karty bez paginacji.

52 Raport polityczny za okres 4-30 czerwca 1948 sporządzony przez Alfreda Fiderkiewicza, 30 VI 1948, AMSZ, DP, 6/28/427, k. 96.

${ }^{53}$ Raport prasowy za okres 15 października - 15 listopada 1948 sporządzony przez Janusza Moszczeńskiego, 15 XI 1948, AMSZ, DPI, 21/94/1272, karty bez paginacji. 
oraz na przemysłowej wyspie Csepel, w których wzięli udział węgierscy robotnicy i podczas których przemówienie wygłosił polski poseł. Szczególnie to ostatnie wydarzenie świadczyło o tym, że Towarzystwo postanowiło objąć swoja działalnością szerokie masy: w wydarzeniu wzięło udział 3000 robotników. W kolejnych miesiacach stowarzyszenie aranżowało kolejne spotkania w świetlicach fabryk oraz zakładów przemysłowych ${ }^{54}$. Zobowiąało się również do organizacji uroczystych obchodów 150 rocznicy urodzin Adama Mickiewicza w 150 węgierskich szkołach ${ }^{55}$. W opinii Alfreda Fiderkiewicza przyjaźń polsko-węgierska zaczęła się rozwijać prawidłowo, a co najważniejsze: obejmowała całe społeczeństwo, natomiast „masy demokratyczne ujmuja je zgodnie $z$ duchem czasu" ${ }^{56}$.

Wraz ze wzrostem tempa działalności Towarzystwa Weggiersko-Polskiego polskie poselstwo coraz mniej uwagi poświęcało Towarzystwu im. Adama Mickiewicza. Na początku 1948 r. Zbigniew Udziela wspomniał o nim tylko raz, relacjonując $\mathrm{w}$ raporcie, że aktywność organizacji wyraźnie spadała ${ }^{57}$. W połowie 1948 r. nastąpił kres samodzielnej działalności Towarzystwa im. Adama Mickiewicza. Jego członkowie otrzymali propozycję przyłączenia się do Towarzystwa Węgiersko-Polskiego jako sekcja kulturalna ${ }^{58}$. Ostatnie posiedzenie odbyło się 6 maja $1948 \mathrm{r}$. Był to koniec istnienia instytucji ${ }^{59}$. Zostało to zapowiedziane przez polska attaché kulturalna Izabelę Czermakowa w kwietniu 1948 r. W raporcie stwier-

${ }^{54}$ Raport polityczny za okres 1 stycznia - 21 lutego 1949 sporzadzony przez Alfreda Fiderkiewicza, 21 II 1949, AMSZ, Wydział Naddunajski [dalej: WN], 7/71/591, k. 4; Raport polityczny za okres 22 lutego - 5 kwietnia 1949 sporządzony przez Alfreda Fiderkiewicza, 5 VI 1949, ibidem, k. 42; Sprawozdanie z działalności Attachatu Kulturalnego za okres 1 lutego - 7 marca 1949 sporzadzone przez Izabelę Czermakowa, 7 III 1949, AMSZ, DPI, 21/97/1297, karty bez paginacji; Sprawozdanie $z$ działalności Attachatu Kulturalnego za okres 8 marca - 5 kwietnia 1949 sporządzone przez Izabelę Czermakowa, 5 IV 1949, ibidem, karty bez paginacji; Sprawozdanie $z$ działalności Attachatu Kulturalnego za okres 5-30 kwietnia 1949 sporządzone przez Izabelę Czermakową, 30 IV 1949, ibidem, karty bez paginacji

55 Sprawozdanie $z$ działalności Attachatu Kulturalnego za okres 1-31 stycznia 1949 sporządzony przez Izabelę Czermakowa, 4 II 1949, ibidem, karty bez paginacji.

${ }^{56}$ Raport polityczny za okres 22 lutego - 5 kwietnia 1949 sporzadzony przez Alfreda Fiderkiewicza, 5 IV 1949, AMSZ, WN, 7/71/591, k. 41.

57 Sprawozdanie prasowe za miesiąc styczeń 1948 sporządzone przez Zbigniewa Udzielę, 4 II 1948, AMSZ, DPI, 21/94/1272, karty bez paginacji.

58 I. Cs apláros, op. cit., s. 75.

59 T. Ge re n csér, A Magyar Mickiewicz Társaság második..., s. 185. 
dziła, że „z chwilą gdy Towarzystwo Przyjaźni Węgiersko-Polskiej zacznie funkcjonować należycie, przejmie $z$ czasem wszystkich członków Towarzystwa im. A. Mickiewicza indywidualnie. Dopóki to nie nastapi obserwujemy pobłażliwie działalność Towarzystwa im. A. Mickiewicza"60.

Żywot Towarzystwa Węgiersko-Polskiego również nie był zbyt długi. W dniu 4 czerwca 1949 r. zostało ono zastapione przez centralną organizację zrzeszajacca wszystkie towarzystwa przyjaźni oraz podporządkowaną węgierskiemu MSZ: Instytut Kulturalnych Kontaktów z Zagranica (Kultúrkapcsolatok Intézete) ${ }^{61}$. Prezesem nowej organizacji został Ernő Mihályfi. Jego oficjalnym zadaniem była praca na rzecz rozwoju relacji kulturalnych między Węgrami a innymi państwami ${ }^{62}$. W rzeczywistości jednak celem nowej instytucji było „ręczne” sterowanie stopniem zaangażowania różnych stowarzyszeń przyjaźni. Należało ograniczać towarzystwa rozwijające współpracę $z$ państwami zachodnimi, natomiast motywować do działania te, które zajmowały się relacjami $z$ państwami bloku komunistycznego. Jedynym wyjątkiem było Towarzystwo Przyjaźni Węgiersko-Radzieckiej, które stanowiło odrębną instytucję ze względu na swoje znaczenie oraz "masowy charakter" ${ }^{63}$.

Powołanie do życia Instytutu było inspirowane istnieniem podobnej instytucji w Zwiazku Radzieckim, gdzie od 1925 r. funkcjonowało Wszechzwiązkowe Towarzystwo Łaczności Kulturalnej $z$ Zagranica. Jego celem było sprawowanie większej kontroli nad relacjami $z$ innymi państwami. Podobne rozwiąanie zostało wprowadzone w Polsce, gdzie w lipcu 1950 r. powołano do życia Komitet Współpracy Kulturalnej z Zagranica ${ }^{64}$.

60 Sprawozdanie $z$ działalności Attachatu Kulturalnego za okres 8 marca - 5 kwietnia 1948 sporządzony przez Izabelę Czermakową, 6 IV 1948, AMSZ, DPI, 21/97/1295, karty bez paginacji.

${ }^{61}$ Telegram Henryka Minca do Wiesława Sobierajskiego, AMSZ, WN, 7/63/533, 24 V 1949, k. 136.

62 A magyar állam szervei 1944-1950, t. I (A-M), red. B. Boreczky, K. Vörös, Budapest 1985, s. 414.

${ }^{63}$ Raport polityczny za okres 1 maja - 7 czerwca 1949 sporzadzony przez Henryka Minca, 7 VI 1949, AMSZ, WN, 7/71/591, k. 175; Raport prasowo-kulturalny za okres 1-31 grudnia 1949 sporządzony przez Janusza Moszczeńskiego, 16 I 1950, AMSZ, DPI, 21/95/1278, karty bez paginacji.

${ }^{64}$ M. Golon, Między stalinowska propaganda a upowszechnianiem kultury. Działalność Wszechzwiazkowego Towarzystwa Łaczności Kulturalnej z Zagranica (WOKS) wobec Polski w latach 1945-1956, „Dzieje Najnowsze” 2006, R. XXXVIII, nr 4, s. 123-124. 
Towarzystwo im. Adama Mickiewicza skupiało osoby, które były oddane idei przyjaźni polsko-węgierskiej, poświęcając jej swój czas, wiedzę, umiejętności, czasem również pieniądze. Pozostawali jej wierni w czasie wielkiej próby, jaka była druga wojna światowa, chociaż mieli świadomość ryzyka, jaka niosła $z$ soba ewentualna niemiecka agresja. Byli gotowi współpracować $z$ komunistami, z którymi dzieliły ich różnice światopoglądowe, byle tylko mieć możliwość kontynuowania swojej pracy. Okazało się jednak, że w realiach reżimu komunistycznego nie było miejsca na organizacje, które korzeniami sięgały okresu międzywojennego. Oznaczało to, że przyjaźń polsko-węgierska została zawłaszczona przez polityków, którzy postanowili wykorzystać ja do realizacji własnych celów, inspirując się dyrektywami płynącymi z Moskwy.

\section{Bibliografia}

\section{Źródea ARChIWALNe}

Archiwum Ministerstwa Spraw Zagranicznych w Warszawie [AMSZ]

Wydział Naddunajski [WN]

Departament Polityczny [DP]

Departament Prasy i Informacji [DPI]

Instytut Pamięci Narodowej Biuro Udostępniania

Zarząd II Wydziału Sztabu Generalnego Wojska Polskiego

Magyar Országos Levéltár

Népművelési Minisztérium 1949-1957

Politikatörténeti és Szakszervezeti Levéltár

Magyar Kommunista Párt

\section{ŹRÓDEA DRUKOWANE}

Antall J., Schronienie uchodźców, Warszawa 2009.

Źródła i dokumenty do dziejów legionistów wegierskich służących $w$ Legionach Polskich w latach 1914-1918, red. E.L. Varga, T. Skoczek, Warszawa 2018.

\section{Prasa}

„Magyar-Lengyel Kurír” 1947. 


\section{OpRacowania}

A magyar állam szervei 1944-1950, t. I (A-M), red. B. Boreczky, K. Vörös, Budapest 1985.

Csapláros I., Zarys dziejów Węgierskiego Towarzystwa im. Adama Mickiewicza: (przyczynki do wegierskiego polonofilstwa w XX wieku), „Rocznik Towarzystwa Literackiego imienia Adama Mickiewicza” 1969, nr 4, s. 63-79.

Gerencsér T., A Magyar Mickiewicz Társaság első évtizede, „Acta Papensia” 2010, R. X, nr 3-4, s. 185-226.

Gerencsér T., A Magyar Mickiewicz Társaság második évtízede, „Acta Papensia” 2011, 3-4 sz., s. 161-201.

Gerencsér T., Grad M., Mitrovits M., Magyar zászló a Visztula felett. Magyar-legyel kapcsolatok a magyar diplomácia szemével, Budapest 2019.

Golon M., Między stalinowska propaganda a upowszechnianiem kultury. DziaŁalność Wszechzwiazkowego Towarzystwa Eaczności Kulturalnej z Zagranica (WOKS) wobec Polski w latach 1945-1956, „Dzieje Najnowsze” 2006, R. XXXVIII, nr 4, s. 123-145.

Kossewska E., Związek Legionistów Polskich wobec byłych legionistów na Węrzech w latach 1938-1939, „Niepodległość i Pamięć” 2009, nr 31, s. 99-110.

Kozocsa S., Mickiewicz na Węrzech, „Pamiętnik Literacki: Czasopismo Kwartalne Poświęcone Historii i Krytyce Literatury Polskiej” 1952, nr 40, s. 463-482.

Magyarok és lengyelek a 19. században. Egy 1944-ben betiltott könyv, ed. M. Mitrovits, Budapest 2018.

Worcell S.G., Stanisław Worcell o stosunkach polsko-węgierskich, Warszawa 1938.

\section{Netografia}

Magyar életrajzi lexikon, t. I, red. Á. Kenyeres, Budapest 1967, http://mek.oszk. hu/00300/00355/html/ABC09006/09681.htm (dostęp: 16 IV 2019). 
Aleksandra Sylburska

UNIVERSITY OF LODZ

\title{
The Polish-Hungarian friendship according to the communists: Polish diplomats towards the Adam Mickiewicz Society in Budapest (1945-1948)
}

\begin{abstract}
A dam Mickiewicz Society was established in Budapest in the interwar period. A Its main goal was to develop Polish-Hungarian cultural relations and popularize the knowledge about Polish lierature in Hungary. It continued its activity during the World War II, despite the fact that Hungary was a German ally. In the post-war period the organization was negatively perceived by Polish communist diplomatic representatives in Hungary. They led to the limitation of Society activity and consequently to its liquidation.
\end{abstract}

Keywords: Adam Mickiewicz Society in Budapest, Polish diplomatic post in Hungary, history of Polish diplomacy. 